\title{
The Role of Microfinance for Empowerment of Poor Women in Yemen
}

\author{
Ali Saleh Alshebami \\ School of Commerce \& Management Science, SRTM University, India \\ E-mail: Talk2aliii@gmail.com \\ Prof. D. M. Khandare \\ School of Commerce \& Management Science, SRTM University, India \\ E-mail: dm_khandare@rediff.com
}

Received: May 4, 2015 Accepted: June 4, 2015 Published: June 5, 2015

doi:10.5296/ijsw.v2i1.7752 URL: http://dx.doi.org/10.5296/ijsw.v2i1.7752

\begin{abstract}
The objective of this paper is to identify the challenges facing the empowerment of women in Yemen. This paper is mainly based on the secondary data collected from the records of the Yemeni Government programmes viz., Social Fund for Development, Microfinance books, websites, official reports and other sources related to the research subject. The mentioned study covers the period from 1997 to 2013 and the area for the study is Yemen. The result of the study reported that there are multiple factors affecting the empowerment of women in Yemen through microfinance such as customs and traditions, high interest rate, financial literacy, wrong religious perceptions, demanded collaterals. However, despite the difficulties and challenges facing women empowerment in Yemen, it is believed that women who are connected to microfinance programs have been positively affected with their households in various aspects as many studies revealed that.
\end{abstract}

Keywords: Microfinance, Empowerment, Yemen 


\section{Introduction}

Throughout the years, woman was considered only as a housewife whose main job is to cook food and care about the children and the husband, due to this perception, she was unjustly treated and faced with many difficulties and obstacles in most societies. This leads to limiting their capabilities, restricting their mobility, reducing their freedom and losing their opportunities to contribute to household income and its improvement. In spite of this unfair treatment, women have proved to be an effective element in many societies. As time passes, women, to some extent, were able to change this negative attitude about them, presently, women are competing with men at everywhere and getting jobs. Women play a double role in every community, they work in productive and reproductive activities to support men and to attain better living standard.

It is believed that in Asia and Pacific Ocean, there is a loss of around USD 42-47 Billion every Year due to the barriers imposed over women's participation in work; it was also revealed that an approximate amount of USD 16-30 Billion is lost every year because of the gab available among gender in education sector (United nation women, nd). It was reported further that in Middle East and North Africa, there is only $40 \%$ of women recognized as active in economic against 100 men (Center for Women Policy Studies, 2003). In another record by the united nation for women, it reported the followings , 53\% of women work in vulnerable employment, women get $70-90 \%$ of the men's income in big countries; women represent $9 \%$ in the construction sector, $12 \%$ in engineering, $15 \%$ in business and finally $24 \%$ in production.

In Yemen, the conservative Muslim country, surrounded by many political and economic obstacles due to some internal conflicts that lead to huge increase in the poverty rate reaching up to $54 \%$ and $60 \%$ for unemployment among youth (World Bank, 2014). The country has been also categorized as one of the fastest growing countries in population with annual growth rate of 3.2 (SFD, 2008). Thus, there was an attempt by the government of Yemen in cooperation with some international donors to alleviate poverty and unemployment in Yemen through the empowerment of disadvantaged women by providing them with different types of small and micro loans and other services to help them get rid of poverty and create good job opportunities. The concept of microfinance was introduced in 1997 by the establishment of the social fund for development, the SFD created a specialized unit called Small and Micro Enterprise Development Unit (SMED). This Unit established two separate entities; the Yemen Microfinance Network (YMN) and Small and Micro Enterprises Promotion Service Agency (SMEPS) for the purpose of providing different kinds of technical training and support to various Microfinance Institutions, Small and Micro enterprises, entrepreneurs and also promoting of microfinance industry in the country. Currently there around 13 MFIs operating in Yemen varies from Microfinance Banks, Programs, foundations, companies and others. The current outstanding portfolio is USD 9,5900 Million and the number of active clients is 99,726 as per the 2013 annual Report of the social fund for development. These institutions provide different types of Microfinance loans and services to unbanked people in the country.

This initiative enabled women clients to start their own enterprises or expand their existing 


\section{Macrothink

businesses, increase the level of confidence and self esteem in the society. Women felt more glad, free and proud because they could notice a change in their household standard of living. The SFD (2008) study revealed that the share of women in Microfinance industry has reached to $82 \%$, other studies stated that only $3 \%$ of microfinance market has been penetrated in Yemen leaving more than 2 million clients un-served (Grameen-Jameel n.d). The current study is an attempt to investigate the role of microfinance in empowerment of women in Yemen.

\section{Literature Review}

SFD (2008) reported that microfinance has increased the income and created job opportunities for microfinance clients in Yemen. Haleem (2012) in a master study reported a negative relationship between illiteracy and women empowerment. In another study conducted by SFD (2009) there was a significant increase in the number of borrowers of more than $87 \%$ since 2005 and no notable difference was observed in repayment rates among male and females.

\section{Methodology}

\subsection{Problem Statement}

The rapid growth in rate of poverty and unemployment lead to the necessity to empower women through different means including microfinance making it as an effective vehicle for women empowerment. Thus this study attempts to answer the following questions:

$>$ What is the role of microfinance in empowerment of women in Yemen?

$>$ What are the challenges facing women empowerment in Yemen?

$>$ What are the possible suggestions for improving the women's empowerment in Yemen?

3.2 Objectives of the Study

$>$ To identify the challenges and difficulties facing women's empowerment in Yemen

$>$ To study the role of microfinance in women's empowerment in Yemen

$>$ To provide some suitable suggestions to improve the status of empowering women in Yemen

\subsection{Importance of the Study}

$>$ The study shall add a new literature to the existing one

$>$ The study shall benefits the decision makers to form suitable solutions to current issues

\section{Socio- Economic Profile of Women in Yemen}

\section{Demographic Indicators in general}

\begin{tabular}{|l|l|l|l|l|l|l|l|}
\hline Year & $\begin{array}{l}\text { Total } \\
\text { Population } \\
\text { (Millions) }\end{array}$ & $\begin{array}{l}\text { Percentage } \\
\text { of female } \\
\text { population }\end{array}$ & $\begin{array}{l}\text { Percentage } \\
\text { of urban } \\
\text { Population }\end{array}$ & $\begin{array}{l}\text { Population } \\
\text { growth } \\
\text { Rate }\end{array}$ & $\begin{array}{l}\text { Total } \\
\text { fertility } \\
\text { Rate }\end{array}$ & \multicolumn{2}{|l|}{ Life expectancy } \\
\hline 2007 & 23 & $49 \%$ & $28 \%$ & $3 \%$ & $5.5 \%$ & Male & Female \\
\cline { 4 - 8 } & & & & & $61(06)$ & $64(07)$ \\
\hline
\end{tabular}




\section{Enrollment ratio}

\begin{tabular}{|l|l|l|l|l|l|l|l|l|}
\hline \multicolumn{2}{|l|}{ Primary Education } & \multicolumn{3}{l|}{ Secondary Education } & \multicolumn{3}{l|}{ Higher Education } \\
\hline Year & Male & Female & Year & Male & Female & Year & Male & Female \\
\hline 2006 & $87 \%$ & $63 \%$ & 2007 & $61 \%$ & $30 \%$ & 2006 & $14 \%$ & $5 \%$ \\
\hline
\end{tabular}

$>$ Women in decision making

\begin{tabular}{|l|l|l|l|l|}
\hline Year & $\begin{array}{l}\text { Members of } \\
\text { Parliament }\end{array}$ & $\begin{array}{l}\text { Women } \\
\text { governmental } \\
\text { Ministerial level }\end{array}$ & $\begin{array}{l}\text { Legislator, senior } \\
\text { official \& } \\
\text { Managers }\end{array}$ & $\begin{array}{l}\text { Professional \& } \\
\text { Technical }\end{array}$ \\
\hline $2007-2008$ & $0.7 \%$ & $2.9 \%$ & $4 \%$ & $15 \%$ \\
\hline
\end{tabular}

Source: Japan International Corporation Agency (23 March 2009).

\section{Current Landscape of Women Empowerment in Yemen}

As per the law in Yemen, women can easily and freely register and own any type of business. There is no restriction on this from the law point of view. Women have the full right to invest and operate any type of business as long as it is not against the law of the country. However, this appears to be visible more on papers than reality because of the complicated problems related to customs and religion. In spite of all this, the study conducted by the social fund for development in 2008 confirmed the growth to $82 \%$ of total microfinance clients of women entrepreneurs who own small and Micro enterprises.

Microfinance Institutions offer different types of products and services to their clients such as individual lending, group lending, village bank, saving, youth loan product, micro insurance, money transfer, money exchange, micro leasing and finally the Islamic micro lending that includes (murabaha, mudarabah and musharakha). These products may vary from one MFI to another. Majority of microfinance institutions offer mixture of productive and services. Both seasonal and consumption loans are offered using both murabaha and cash transaction. Loans are available for both start up and existing business depending on the institution. The size of loan also varies from one pogramme to another ranging from YR 5000 to 50,000, the loan may reach up to YR 500,000 and the repayment period would be 6-12 months. The average loan size is USD104.

The microfinance social issues cannot be solved easily; they need tremendous effort to change the mentality of people and to enhance the necessity of the women's empowerment concept in the development of the livelihood. Islamic Microfinance might play a role in changing this attitude though people still look at it with suspension. The chances for mobility of women are still very limited due to the restrictions and barriers of the society, most of their activities are home based. Different studies of SFD demonstrated that the majority of poor women clients are engaged in small scale enterprises such as sewing, incense manufacturing, hairdressing, animal husbandry, buying and selling of clothes, perfumes, and various other small businesses. However there was no special exclusive training program for women to improve their skills despite the effort made by small and micro enterprise promotion agency 
(SMEPS) in conducting training programs such as the business edge program (BE), handicraft export promotion program (HEPP), value chain development programs, consultation programs, know about business programs (KAB), new business lines, technical advisory stations (TAS), exhibitions and finally the exposure visits. Concerning to training, only few women received formal training from specialized organizations, majority learnt either by themselves or took help from their relatives or neighbors, for those who received some training courses. It was found that there was no link between the attended courses and credit access leaving many without the financial resources necessary to switch their training into a sustainable livelihood.

\section{Significance of Group Approach Among Women}

Group lending is one of the most important approaches employed by microfinance institutions to provide small and micro loans to disadvantaged people who lack access to credit and do not have collaterals to guarantee the loans. In Yemen, this type of lending methodology was introduced in 2002 when ASA microfinance foundation of Bangladesh started working on the establishment of national microfinance foundation (NMF), since that time it has been almost replicated in all MFIs in Yemen. The loan is usually less than YR 50,000. However in a country like Yemen, for a woman to obtain a loan from any microfinance institution, a permission has to be granted from her husband or family leader plus a guarantee from any salaried person to be submitted to the credit supplier, this means that this type of lending is not really working effectively in Yemen market due to many restrictions. The social and cultural barriers are really hampering the improvement of women empowerment, they limit the chances for low income women to obtain the loans and prevent them from carrying out any business activity that might participate in the development of the household.

In many cases, women are denied from loans because of their husband's rejection which makes it very difficult for MFIs to operate and explain the situation to their husbands. Group formation is done usually by family members or neighbors, total number of the group might reach up to 23 members; this type of group makes a better chance for interaction, supporting and marketing for each other. When women are brought together, especially, those who have restrictions on mobility, Microfinance Institutions can get a chance to enhance social development and empowerment for them. It is indeed very essential to find an alternative solutions to this issue so that the group approach can play the role of development especially in a country where human development indicators are too poor, in fact, there is no proper use for group approach in the development and promotion of women empowerment, thus some immediate corrective actions have to be taken in this regard.

\section{Impact of Micro Finance on Women Empowerment}

Microfinance has been defined by CGAP as "The provision of financial services to low-income people". The term microfinance does not only mean the extension of small loans to disadvantaged people, it further includes different types of small products and financial services such as saving, insurance, micro leasing. The term microfinance has its root in microcredit which has been evolved in latest decades, it is considered to be one of the new tools used for poverty and unemployment mitigation in various developed and developing countries including Yemen. Despite of the short experience of microfinance institutions in this industry, it is believed that considerable social, economical and political changes have 
been done to the women microfinance clients in the country. The previous conducted study by the social fund for development (2008) confirmed the positive effect of microfinance over poor women in decision making, assets purchasing, self reliance and participating in the improvement of the household standard of living in spite of the conservative traditional and restrictions imposed over women by the society.

Microfinance is a good chance for countries to get rid of poverty and to create new job opportunities for unemployed people, develop home based businesses. It offers them an easy access to funds that contribute to better living standard for their families. These micro and small loans play a vital role in assisting husbands and children to overcome the financial difficulties faced in life. Women in many studies reported their benefits from the participation in microfinance programs, this participation lead to greater independence, more freedom, and improvement in their business skills, better self esteem, and more self confidence. The opportunities to take decision in the family and outside increased and their economic situation improved, resulting in increasing their income and securing their future.

On the other side, some findings (SFD, 2008) reported a negative view of women towards microfinance and being a part of it, they declared that it increases their livelihood responsibility, increases their stress and tension, loses the control and balance between the house duties and work activities, increases the worries about the repayment of the loan back and finally the problems arising out of carrying out business. Still with all these difficulties and limitations, women believe that microfinance is worth risking as evidenced by their level of participation with $82 \%$ in social fund pogramme referred to earlier. The slow growth of Microfinance appears to have some challenges facing women empowerment through microfinance. These challenges can be illustrated in the next section.

\section{Challenges and Obstacles Facing Empowering of Women in Yemen}

The industry of microfinance in Yemen faces a lot of difficulties and obstacles especially with women clients. Many challenges have been reported in different studies conducted by the Social Fund for Development and other gender studies. The researcher further adds his own point of view to these challenges. The major challenges can be illustrated in the following points:

1- The existence of very conservative lending practices which hinders the possibility of women to obtain loans and contribute to the improvement of their household standards of living.

2- The demand for collaterals and guarantees for loans extension hampers the development of the home based conventional activities and restrict the growth of business.

3- Improper use of group approach to support women empowerment economically and socially results into the loss of the opportunity to more social change over women.

4- The religious attitude towards conventional lending limits the possibility of women to apply for loans from microfinance institutions.

5- The negative perceptions of the society's members especially in northern and middle cities against women who want to start their own businesses restrict and demotivate them to apply for loans. 
6- The lacks of marketing skills, knowledge about the market and marketing activities lead to losing the amount invested in the enterprise.

7- Absence of proper technical training and support to women making them rely mainly on their relatives or experts in the field.

8- The extension of very small loans does not really serve the purpose of the women clients especially if it needs long period of time to graduate from one loan to another.

9- The very high interest rate creates fear in women regarding the ability to repay it back which lead to not applying for the loan.

10- Shortage in the innovation and availability of repetition of products and services in microfinance institutions result in freezing of the micro finance market.

11- The graduation of loan level from one to other is very slow.

12- The fear of women to take responsibility of business frustrates women to get rid of microfinance idea.

13- No enough knowledge or awareness among women about resource management, budgeting control and other commercial functions available.

14- Lack of innovations in Islamic Microfinance as no new products and services developed to meet women's needs.

\section{Indicators for Women Empowerment through Microfinance}

It is very essential to know the effect of microfinance over women empowerment and for that it is necessary to investigate this impact with the help of some economic, social and political indicators, these indicators are used mostly by researchers to identify whether the microfinance has really helped in making some positive changes in the life of women households or not. Some of the major indicators employed when impact assessment is conducted are stated below:

\subsection{Economic Indicators}

Economic empowerment indicators focus mainly on the economic status of the woman, they investigate whether microfinance has lead to additional income, created new employment opportunities, contributed to the savings of the household, allowed the control over the available resource, gave a chance to open saving account in the bank and finally participated in decision making inside the family and outside.

\subsection{Socio-Cultural Indicators}

The socio-cultural indicators concentrate more on how far has the woman become freer, confident, self reliant, gained strength to move out to purchase goods from market, obtained a better education level for her and her family members and finally participation in local issues.

\subsection{Political Indicators}

These indicators concentrate on how far the woman has been able to exercise her right in voting and fighting for their right in society, participating in important meetings that might affect her future.

\subsection{Business and Soft Skill Indicators}

These indicators are related to examining the ability of woman to read and write, literacy level, ability to record daily transactions, understanding the basic concept of banking 
processes , reading newspapers and finally on and off job training.

\section{Suggestions}

1- $\quad$ There is an urgent need to spread awareness among people of the country about the importance of empowerment of women and their role in supporting the household.

2- $\quad$ There should be especial regular training programs to microfinance women client to provide them with the required consultation and technical training required for their activities and other aspects.

3- $\quad$ There is a necessity to work on the development of special products and services for women which change the negative attitude towards them in the society

4- The government must provide a suitable infrastructure and safe atmosphere for women to market their products and services.

5- The microfinance institutions should focus on educating poor people especially women about the need and importance of microfinance especially for unbanked.

6- $\quad$ The commercial banks have to downscale their activities to reach to unbanked women clients so that poverty and unemployment among women can be reduced.

7- $\quad$ There must be a serious cooperation between the Islamic microfinance institutions and the traditional microfinance institutions to work together to empower women with new innovative products and services.

8- $\quad$ The government should take help from leaders and tribal sheikhs in motivating poor rural families to participate in microfinance programmes.

9- Women must be taught as how to balance between the business activities and the house duties so that no problems can occur.

10- Microfinance institutions should work on reducing the interest rate, easing the loan procedure, and remove the clause that insists on getting the husband's permission for granting loan to woman so that women can be motivated to apply for loans.

\section{Conclusion}

Empowering of women has become very important these days. It plays a crucial role in pushing them and making them cable of carrying out different types of small and micro enterprises which help in improving the standard of living of their poor households. The essence of the empowerment appears in giving them an opportunity to be self reliant and self confident, it further enables them to become an active member of the family who can participate in decision making and other related issues. Women empowerment is simply the process by which women are made capable, financed, educated and equipped with assets and funds to start a new small business or to support an existing one.

Women empowerment through microfinance is an effective tool that empowers them to participate in poverty reduction of their family and give them a chance to create new job opportunities. It also helps in securing their food and educating children in the family. On the other side, women reported some negative opinions about this empowerment, they say, it increases the stress and tension of women about the loans borrowed from the MFIs, creates a situation where household's duties and business activities are not balanced and finally generate problems where business is operated. Socio-economic and political indicators can be 


\section{Macrothink

used for measuring the effect of microfinance programmes over women, they investigate whether women have really benefited or not. Empowering of women should lead to access of fund, new job opportunities, contribution to household income, gaining freedom on mobility, ability to claim their right, ability to learn and various other positive aspects.

\section{References}

Abdohaleem et al. (2013). The current realtionship between Culture and Microfinance in Yemen. Yemen-Sanaa.

Central Statistical Organisation. (2013). Statistical YearBook 2013. Yemen-Sana'a: Central Statistical Organisation .

CGAP. (2014). The Consultative Group to Assist the Poor. Retrieved from http://www.cgap.org/about/faq/what-microfinance-how-does-it-relate-financial-inclusion-0

Jameel, G. (2014). Retrieved from http://grameen-jameel.com/yemen/

Social Fund For Development. (2010). SFD 2009 Impact Evaluation Final Report . SFD.

Social Fund for Development by Adel Mansour. (2011). Small and Micro Enterprises Development in Yemen and future prospects. Sanaa: SFD .

Social Fund for Fevelopment by Deena Burjojee \& Mary Jennings. (2008). Microfinance Gender study: A market Study of Women Entrepreneurs in Yemen. Yemen, Sana'a: Social Fund For development .

The social Fund for Development. (2013). Yemen-Sana'a: Social Fund For Development.

The World bank. (2014). The World Bank.

The World Bank. (2014). Yemen Overview. Women, The Global Fund For. (2014). Status of Women Around the World, Facts and Figures.

\section{Copyright Disclaimer}

Copyright reserved by the author(s).

This article is an open-access article distributed under the terms and conditions of the Creative Commons Attribution license (http://creativecommons.org/licenses/by/3.0/). 